\title{
An analysis of functional insole on foot pressure distribution of shape memory material combinations
}

\author{
Seung-Bum Park, Kyung-Deuk Lee, Dae-Woong Kim, Jung-Hyeon Yoo, Kyung-Hun Kim
}

From 4th Congress of the International Foot and Ankle Biomechanics (i-FAB) Community

Busan, Korea. 8-11 April 2014

The purpose of this study was to analyze foot pressure distribution of shape memory materials functional insole. Comfort is an important aspect for footwear and insole. Footwear and insole comfort has an influence on injury $[1,2]$. The development of new materials is considered as the important point for manufacturing functional insole $[3,4]$.

Ten healthy male (mean height: $174.7 \pm 4.0 \mathrm{~cm}$, mean body mass: $71.0 \pm 8.0 \mathrm{~kg}$, mean age $23.9 \pm 0.3 \mathrm{yrs}$.) were participated in this study. All subjects were free of lower extremity pain, history of serious injuries or operative treatment or subjective symptoms interfering with walking. Each subject's foot was pre-screened by Podoscopy (Alfoots, Korea) to see if they had any foot abnormalities.

The subjects were required to normal walking $(4.2 \mathrm{~km} / \mathrm{h})$ for treadmill. Each subjects was seven different insole type (A $\sim \mathrm{G}$ type, figure 1) during walking. The PEDAR ${ }^{\mathbb{B}}-\mathrm{X}$ insole system (Novel GmbH, Germany) was used to

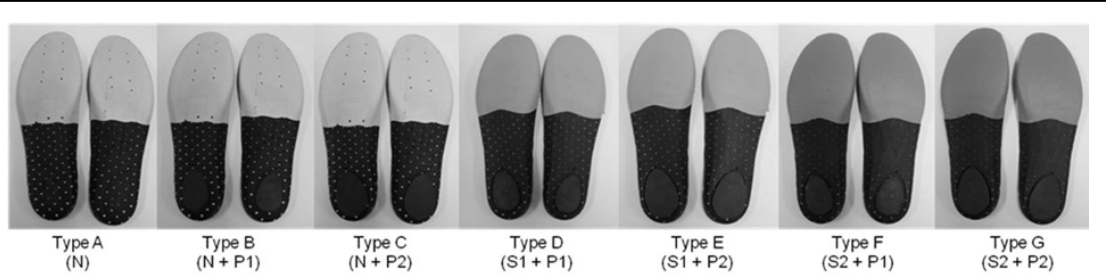

Figure 1 Tested seven types insoles (L-R): Type A G. N: normal material, S1: low hardness shape memory material, S2: high hardness shape memory material, P1: low hardness Poron ${ }^{\circledR}$ material, P2: high hardness Poron ${ }^{\circledR}$ material.
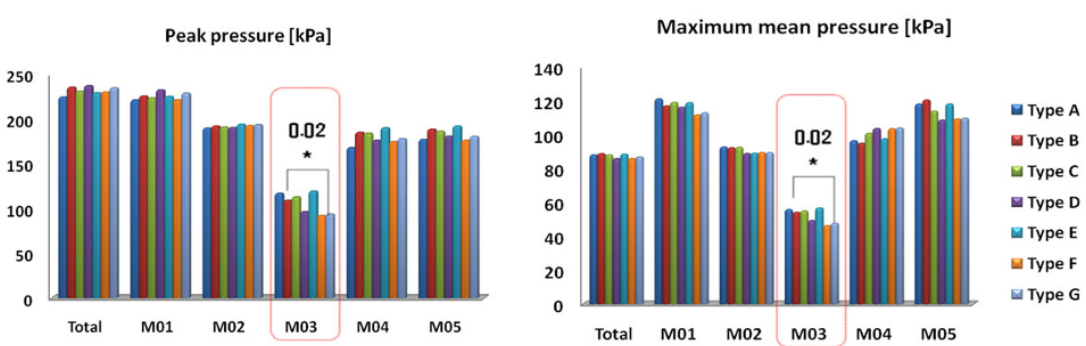

Figure 2 Comparison of foot pressure of the seven types insoles.

\footnotetext{
* Correspondence: sbpark@shoenet.org

Footwear Biomechanics Team, Footwear Industrial Promotion Center, Busan,
} Korea 
measure the foot pressure and force. Pressure distribution data (peak pressure, maximum mean pressure) was collected with pressure device at a sampling rate of $100 \mathrm{~Hz}$. The feet were divided into six regions: foot (Total), lateral forefoot (M1), medial forefoot (M2), midfoot (M3), lateral rearfoot (M4), and medial rearfoot (M5).

Comparison of foot pressure is show in figure 2. In the midfoot (M3) area, a significant different was found between insoles in peak pressure and maximum mean pressure. The type F and G insoles decreased the peak pressure and maximum mean pressure.

Published: 8 April 2014

\section{References}

1. Nigg BM, Hintzen S, Ferber R: Effect of an unstable shoe construction on lower extremity gait characteristics. Clinical Biomechanics 2006, 21(1):82-88.

2. Ramanathan AK, Kiran P, Arnold GP, Wang W, Abboud RJ: Repeatability of the Pedar-X in-shoe pressure measuring system. Foot and Ankle Surgery 2010, 16:70-73.

3. Kim EH, Cho HK, Jung TW, Kim SS, Chung JW: The Biomechanical Evaluation of Functional Insoles. Korean Journal of Sport Biomechanics 2010, 20(3):345-353.

4. Ko EH, Choi HS, Kim TH, Roh JS, Lee KS: Effect of the Fatigue to Insole Types During Treadmill Exercise. Physical Therapy Korea 2004, 11(2):17-25.

doi:10.1186/1757-1146-7-S1-A120

Cite this article as: Park et al:: An analysis of functional insole on foot pressure distribution of shape memory material combinations. Journal of Foot and Ankle Research 2014 7(Suppl 1):A120.

\section{Submit your next manuscript to BioMed Central} and take full advantage of:

- Convenient online submission

- Thorough peer review

- No space constraints or color figure charges

- Immediate publication on acceptance

- Inclusion in PubMed, CAS, Scopus and Google Scholar

- Research which is freely available for redistribution

Submit your manuscript at www.biomedcentral.com/submit 